\title{
Christian-Muslim Coexistence in Peshawar City
}

\author{
Khaista Rahman ${ }^{1} \&$ Muhammad Akram ${ }^{1}$ \\ ${ }^{1}$ Department of Comparative Religion, International Islamic University, Islamabad, Pakistan \\ Correspondence: Muhammad Akram, Department of Comparative Religion, International Islamic University, \\ Islamabad, Pakistan. Tel: 92-332-512-6427. E-mail: m.akram@iiu.edu.pk
}

Received: February 12, 2020

doi:10.5539/ass.v16n4p30
Accepted: March 13, $2020 \quad$ Online Published: March 30, 2020

URL: https://doi.org/10.5539/ass.v16n4p30

\begin{abstract}
Several scholarly works and media reports claim that the Christian minority in Pakistan is mistreated, persecuted, and discriminated against, giving an overall impression as if Christians are alienated from the main social stream everywhere in Pakistan and that the public at large is responsible for their miseries. Noticing that most of the above-mentioned works are theoretical or based on journalistic information, an attempt has been made through this empirical case study of Peshawar city to know the situation of Christian-Muslim coexistence on the ground. For this purpose, a mix method approach was used combining quantitative survey, qualitative interviews, and group discussions. Contrary to the prevailing negative impression, this study reveals that to a large measure Christian and Muslim communities are living together peacefully, at least in Peshawar city. Quantitatively, 68\% of respondents, both Christians and Muslims, viewed their mutual social and neighborhood interaction as positive. The results of qualitative interviews also supported these findings. It is, therefore, concluded that apart from some Christian concerns which need to be addressed, overall Christian-Muslim coexistence at the societal level might not be marred by religious differences everywhere in Pakistan. Negative generalizations in this regard need to be revisited, to say the least.
\end{abstract}

Keywords: Christians, Muslims, minorities, neighborhood, social interaction, coexistence, Peshawar

\section{Introduction}

\subsection{Background}

Pakistan came into being in 1947 as a separate homeland for Muslims of the Indian subcontinent where they could live by their religious aspirations and safeguard their economic interests. Today, Pakistan is a country with an overwhelming Muslim majority. According to the census of 1998, Muslims are $96.28 \%$ of the country's population, while Hindus are $1.6 \%$ and Christians $1.59 \%$ (Pakistan Bureau of Statistics). Muhammad Ali Jinnah (1876-1948), who spearheaded the freedom movement of Pakistan, had declared in clear terms that minorities would have full religious and cultural freedoms with equal citizenship rights like their Muslim compatriots (Malik, 2002). Thus, the constitution of Pakistan promises adequate provisions for minorities of the country to profess and practice their religion and develop their culture (2012, pp. 12-16). However, religious minorities of the country in general and the Christian minority in particular often complain about different types of political, legal, and social discrimination.

Several academic works and situation reports portray a quite dismal picture of the situation of minorities in Pakistan. Though most of these writings discuss the majority-minority relations in the context of wider historical, political, economic, and security parameters, one gets an impression from them as if social interaction between the majority Muslim population of the country and its minority communities would also be quite hostile. However, there is a lack of empirical studies on social interaction between different faith communities in Pakistan. Thus, it is imperative to move ahead of thematic studies and generalized assertions and empirically study social interaction, more specifically neighborhood interaction, of Pakistan's religious minorities with the majority Muslim population using social scientific methodologies.

Needless to emphasize, any social scientific study needs to focus on a well-defined population for the sheer purpose of feasibility and also to find out specific facts that can be used for scientifically plausible conclusions. Christian-Muslim coexistence and social interaction in Peshawar city make a good case study for at least two reasons. Firstly, the majority of Peshawar's Christians are ethnically Punjabis living amongst larger Pashtun and Hindko ethnicities of the city. In other words, they are both ethnic and religious minority in the City. Moreover, 
conflicting claims have been made about the situation of minorities in Peshawar. At least one study claims that the Khyber Pakhtunkhwa (KPK) province of Pakistan, with Peshawar as its provincial capital, is a better place for minorities to live in Pakistan (Khan \& Rafi, 2014). However, the matter of fact is that violence has occurred against the Christian minority in Peshawar as well. For instance, 85 people died in September 2013 when All Saint's Church was attacked with bombs by terrorists. On that occasion, Mano Rumal Shah, the bishop of Peshawar, had warned that the future for Christians was not safe in the country (2013). Some three years later, in September 2016, a terrorist attack on the Christian colony, on the outskirts of Peshawar, was foiled by the security forces (Yusufzai, 2016). Against the background of such contradictory claims and incidents, an empirical study of the Christian-Muslim social interaction in Peshawar has the potential to yield interesting results. Such a case study can help better understand the majority-minority relations in Pakistan at the grassroots level.

It may be noted that Peshawar is also an administrative district, which includes some rural areas where Christians reside but the population of this study is delimited to only those locales that fall within the city boundaries, such as big Lal Kurti, small Lal Kurti, Swati Patak, Academy Town, Nothia, Kohati gate, Yousaf Abad, and the University Campus.

\subsection{Coexistence and Social Interaction}

Coexistence means living together of two or more entities at the same time and space. The minimum level of coexistence is achieved when various communal groups "live together without one collectively trying to destroy or severely harm the other (Kriesberg, 2001)." An important factor that indicates the peaceful coexistence of various religious, ethnic or other cultural groups in a shared social space is the level of their mutual integration. Integration, in turn, depends on social interaction between members of the coexisting groups (Ibid)

The term interaction comes under micro-sociological studies of social processes. It involves face-to-face encounters and the settings in which people act with one another (Elliott, 2006, p. 304). Social interaction does not only mean verbal communication but also a non-verbal communication with each other. People relate themselves to each other, perform different actions, do tasks and live their lives (Yusof, 2006). R. J Rummel states that Social interactions are those activities which a person performs towards another person. Further, he maintains that any behavior which attempts to impact each other's intentions is included in social interactions (1976, Ch: 10). Thus, it becomes clear that social interaction is a social process of action and reaction of people towards each other. This process is represented in a mutual relationship between two or more individuals or groups. Hence, if a person, group or community is talking, chatting, communicating or celebrating with another person, group or community on a specific topic, issue or event whether political, religious or social, we can say that they are interacting with each other. The two main components of social interaction are social contact and communication with each other. Then social interaction can be negative or positive (Mondal). The present research aims at studying the nature of contact and communication between Christians and Muslims in Peshawar, and whether their mutual interaction is negative or positive. Within various types of social interaction, the main focus of the study is on neighborhood interaction.

\subsection{Christian Community of Peshawar}

Peshawar is the capital of the Khyber Pakhtunkhwa (KPK) province of Pakistan. The Peshawar Diocese states that around 165,000 Christians live in KPK out of which about $60 \%$ belong to various protestant denominations and approximately 40\% are Catholics (Peshawar Diocese). According to the 1998 Census, the total population of Peshawar city was 982,816 out of which 17,563 were Christians (Pakistan Bureau of Statistics). The Minorities Rights Group International claims that the current Christian population of Peshawar city is 70,000 (2018).

Out of the eight dioceses of the Church of Pakistan, one is Peshawar Diocese whose area coincides with that of the provincial territories of KPK. The Peshawar Diocese was originally a part of the Anglican Church of Lahore. After the Church Union in 1970, the territory of KPK province, then called North-West Frontier Province (NWFP), remained part of the Lahore Diocese. In 1980, the territory of Peshawar was separated and elevated to the level of a diocese. The office of this diocese is located in Saint John's Church on Sir Sayyed Road, which is the oldest Protestant church in the city, being built in 1850 (Ali, 2013). Historically, Christianity came to Peshawar in the nineteenth century during the British raj. In 1853, Sir Herbert Edward, (Note 1) the British Commissioner of Peshawar, established the Edward Mission High School in Rethi Bazaar near Chowk Yadgar Peshawar. Sometime after its establishment, the school was shifted to the Kohati gate (Ihsanullah, 2013) which exists to this day. In the beginning, the Christian congregation used to worship in this school (Jan, 2013). Afterward, the Church Missionary Society came to Peshawar in 1854, which had close connections with British officials. The first team of this missionary venture was K.G. Pfander, Robert Clarke, and Major Martin and it 
was due to the struggle of these missionaries that the New Testament was translated into Pashto in 1863 (Zafar, 2000, p. 89). Later on, the missionaries built All Saints Church in 1883, at the opening of Koochi Bazaar (Jan, 2013).

Saint Michael's Catholic Church is the oldest Catholic Church in the city. It was constructed in 1851. (Note 2) It is located on the Mall road close to Sadder. The church shares a boundary wall with Jamia Uloom-ul-Islamia. Another church, Saint John Vianney's Catholic Church is situated on City Circular Road. It was built in 1937 (Note 3). Both Saint Michael and this church work under the Roman Catholic Diocese of Islamabad-Rawalpindi. Other churches in Peshawar include Seventh-Day Adventist Church on the opposite side of Saint John Church in the cantonment area, Catholic Church, New Apostolic Church and Salvation Army Church in Rural Academy Town, United Church in University Campus, and Assembly of God Church in Naseer Abad.

In 1972, when Pakistan Peoples Party's government tried to impose its nationalization policy in Pakistan, the provincial government led by the alliance of National Awami Party and Jamiat-Ulma-e-Islam, with Maulana Mufti Mahmood (1919-1980) as Chief Minister, refused the policy of nationalizing any educational institutions of the province. Thus, Christian schools and colleges continued serving in KPK continuously since the 19th century while in the rest of Pakistan many of these institutions remained nationalized for about four decades. Today, numerous Christian educational institutions are functioning excellently, like Edward College, Peshawar, Edward's School Peshawar, Pennell School Bannu, among many others (Shamsi, 2011, p. 89).

Ethnically, the Christians of Peshawar are mostly Punjabis. This means that they are both religious and ethnic minority in Peshawar. They speak Punjabi, Urdu and to some extent Pashto dialects. They dress like Pashtuns which implies an inclination to adjust to local culture.

\section{Literature Review and Research Questions}

\subsection{Literature Review}

There is a huge literature on the condition of minorities in Pakistan which gives generally a negative impression about the status of religious minorities in Pakistan as inferior compared to the Muslim majority of the country. For instance, Ajay K. Rainaa (2014) writes: "Pakistan's minorities are woefully small and politically powerless... Minority representation is small, qualitatively poor and structurally tied to the majority's largesse." S.S. Akbar Zaidi (1988) talks about the perpetual fear of violence that the minorities in Pakistan are faced with. Roger Ballard portrays an even more dismal picture of their state of affairs and uses the term 'ethnic cleansing' while describing the treatment of the majority with the religious minorities in Pakistan. In his own words:

[T]he formal institutions of the state are both unable and unwilling to offer significant protection to those who find their lives threatened by an ever more powerful collection of neo-fundamentalist non-state actors who are ready and willing to teach their chosen targets amongst Pakistan's religious minorities (and now those who speak up for their rights as well) a lesson: namely that their only proper fate is to be subjected to ethnic and religious cleansing. (2015)

Rehman and Zia review various educational policies of Pakistan and find some of them problematic for the country's religious minorities (2010). Another study maintains that textbooks of social and Pakistan studies create a negative and hostile image of the country's religious minorities (Ghazi, Shahzada, Khan, Shabeer, \& Shah, 2011). Similarly, Ahmed, Hassan and Shahzad (2014) opine that: "Media in Pakistan is also playing a little bit biased role in the reporting of issues related to religious minorities." More importantly, according to a report of the National Commission of Justice and Peace (2011), the marginalization of minorities exists in the whole social system. Thus, these writings create an impression that minorities in Pakistan are discriminated against, mistreated, and threatened everywhere in Pakistan, and that the public at large is responsible for their sorry state of affairs.

Speaking specifically about the Christian minority, Gabriel (2007, p. 103) discusses legal, religious, security, educational and other problems faced by Christians in Pakistan. He concludes that the "state of Christian-Muslim relations in Pakistan seems to present a bleak picture." Gregory (2008) argues that the Christian's persecution and killing in Pakistan took momentum after 9/11. He maintains that after this incident many Christians have been killed. He further states that every year thirty to fifty Christians are murdered due to their religious faith. Besides killing, he claims that thousands of Christians are facing severe pressure and oppression from the Muslim community. By giving some statistics of the supposed Christian persecution from 2001 till 2008 , Gregory concludes that Christians are persecuted across the whole Pakistan including Peshawar, Murree, Islamabad, Lahore, and Karachi. He further asserts that the violence against Christians is sometimes patronized by the state on the government and local levels (Ibid). Misra relates the perceived persecution of the Christian 
minority in Pakistan with extremist Islamist ideology (2015). Recently in December 2015, Pakistan Christian Post published an interview of a Christian woman in which she is reported to have said: "Life for Christians in Pakistan is now worse than ever: we are attacked daily and treated worse than rats. Muslims do not want us as their neighbors because they believe we are evil and have satanic diseases." (Smith, 2015).

Some studies specifically deal with Christian-Muslim interaction in Pakistan and the social status of Christians. One such study is a report published by Immigration and Refugee Board of Canada (2013) which claims that the overall Muslim attitude towards Christians is negative and that Muslims consider them untouchables due to their lowest social status and backward caste before conversion to Christianity. On the other hand, Moeller, Love, and Micheli (2011) argue that the overall Christian-Muslim relations have improved after 9/11. They state that it is media which holds people back to see progress in Christian-Muslim relation. According to them, the journalists selectively pick up certain events and sometimes they frame them in a different context to create negativity about the Christian in the eyes of the general public. They do report violent attacks committed against Christian minorities in some Muslim countries but for them, such crimes take place everywhere including the most liberal societies like America where Muslims are facing the heightened prejudice and aggression from a particular segment of the American population. In short, according to them the overall Muslim-Christian relationship is improving Khalid and Tarar (2004) have studied inter-group perceptions of Christians and Muslims in Pakistan and conclude that apart from religion social status also affects their mutual perceptions. Similarly, Shamsi has written a Ph.D. thesis on Social Status of Christians in Pakistan in which he concludes: "Pakistan's overwhelming majority is tolerant and in favor of giving equal rights to minorities and women" (2011, p. 157). Unfortunately, the study does not touch upon every day and neighborhood interaction of the minority Christians with the majority of Muslim Pakistanis.

Concerning media depictions of Christians in Pakistan, Rebecca Seiler claims that the media is unfair towards Christians and airs biased reports against them which renders it equally responsible for aiding and abetting in their persecution (2014, p. 7). Contrary to Seiler, Mubeen and Qusien (2017) argue that Pakistani TV channels are successful in creating awareness among the general public about minorities' rights and effectively highlight their issues through their objective analysis. In the same vein, Ambreen's (2014) study on English print media concludes that newspapers such as Daily Dawn, The News, and The Nation give positive coverage to minority issues.

Against the backdrop of such studies, Khan and Rafi (2014) raise an interesting point from another angle. They argue that Pakistani society should not be taken as a monolithic entity. Thus, according to them, Christians of KPK enjoy more peace as compared to other provinces of the country like Punjab. However, the lacuna of this study is that it makes a specific comparative statement about KPK and other provinces of Pakistan like Punjab on the bases of randomly selected individual examples. Although the paper laments some Christian authors for their attempt to disproportionately focus on negative incidents, the study itself does the same when it comes to comparison between KPK and Punjab. While another report (Yousaf, 2016) concludes that the plight of minorities in Pakistan is the same everywhere in the country, it points to the demographic differences and maintains that Punjab is more radicalized than Sindh.

\subsection{Research Questions}

The religious minorities in Pakistan are portrayed as a discriminated-against class facing the challenge of peaceful coexistence. The Christian minority of Pakistan is especially claimed to be alienated and persecuted. The question is if and how far the everyday social interaction between the Christian minority and Muslim majority corroborates such negative perceptions? Secondly, does the thesis of alienation and persecution of Christians in Pakistan equally apply to every part of the country?

\section{Research Methods}

In this study, neighborhood interaction is used as an indicator. By neighborhood interaction the researchers mean every day and practical socialization and coexistence of Christians and Muslims in their neighborhood. The study attempts to find out how both the communities perceive each other, how often they visit each other, if they celebrate festivities together, and do they help each other?

A mix method approach (Pennink \& Jonker, 2010, pp. 94-96) has been employed in this research. Hence, data were collected through questionnaires, interviews and group discussions. The defined sample size for quantitative analysis was 384 respondents. We used simple random technique and adopted the lottery method for the selection of our respondents (Singh, 2006, pp. 86-87). Out of 384 questionnaires distributed 33 were not returned and 3 questionnaires received were not completely answered. Since, this was a small scale study; therefore the number of questionnaires was reduced to 348 respondents. 
Moreover, the qualitative questions which could not be delivered through questionnaires were asked in interviews and group discussions. For qualitative analysis, Semi-structured interviews were held with 10 persons (5 Christians and 5 Muslims) including 6 notable religious scholars. Out of 6 religious scholars, 3 were Christians and 3 Muslims. Apart from the individual interviews, three group discussions (each group consisted of 5 participants) were held only with the Christian respondents who were purposely selected. In group discussions, only those Christian respondents were included who had routine interaction with their Muslim neighbors.

The questionnaire was analyzed by using SPSS Software. The data thus accumulated is then presented below in the form of tables. However, some calculations were also done manually to make the data easier and understandable to common people. The data obtained through interviews and group discussions have been used to triangulate with the quantitative data.

\section{Data Analysis}

\subsection{Demographic Data of the Respondents}

The first part of the questionnaire consisted of questions such as religious belonging, age, gender, educational level, marital status, profession, duration of stay in the community and monthly income of the responders. As the study was about to inquire about social interaction among Christians and Muslims therefore, the category of religion was divided into two groups, that is Islam (48.9\%) and Christianity (51.1\%). The age category of the respondents was divided into four groups; 18 to 24 (28.8\%), 25 to 30 (23.0\%), 31 to 39 (24.7\%), 40 and above $(23.5 \%)$. Gender was categorized into two that are male $(77.91 \%)$ and female $(22.09 \%)$. Education level was categorized into seven groups; none (8.4\%), Primary (7.5\%), Middle (13.6\%), Matric (20.8\%), Higher Secondary (25.7\%), BA (14.5\%), Master and above (9.5\%). Marital status was divided into three categories, married (56\%), single (39.9\%) and widowed (2.9\%). The profession category of the respondents was divided into five groups; $23.1 \%$ of the participants were government workers, $35.4 \%$ were private servants, and $12.9 \%$ of the participants had their own business. $19.6 \%$ were students and $9.06 \%$ had no job. $40 \%$ of the respondents were staying in their community from 41 years and above. Duration of stay in community was; $20.29 \%$ were living in their community from 31-40 years, $16.2 \%$ of the respondents were staying from 21-30 years, while $13 \%$ were residing between 11-30 years. Monthly income was calculated as $12.9 \%$ of the respondents were earning PKR 10000 and below, 31.7\% were earning between PKR 11000 and 20000 per month, 18.2\% were earning between PKR 21000 and 30000, 5.6\% were getting between PKR 31000 and 40000 per month. 3.81\% of respondent's monthly income was between 41000 and 50000, 1.5\% were earning PKR 51000 and above.

\subsection{Neighborhood Interaction}

Seven questions were designed for measuring neighborhood interaction between Christian and Muslim communities. The respondents were asked to select a suitable option based on the Likert type scale of one to three. The data is explained below.

Table 1. Do you know your Muslim/Christian neighbors?

\begin{tabular}{cccccc}
\hline Christians' Response & Frequency & Valid Percent & Muslims' Response & Frequency & Valid Percent \\
\hline All of them & 121 & 68.0 & All of them & 100 & 58.8 \\
Some of them & 57 & 32.0 & Some of them & 65 & 38.2 \\
None & 0 & 0 & None & 5 & 2.9 \\
Total & 178 & 100 & Total & 170 & 100 \\
Missing & 0 & 0 & Missing & 0 & 0 \\
Total & 178 & 100.0 & Total & 170 & 100.0 \\
\hline
\end{tabular}

Question one sought to find out whether Christian and Muslim neighbors know each other. Table 1 points out that $68 \%$ of Christians knew all Muslim neighbors while 32\% knew some of their Muslim neighbors. 58.8\% Muslims reported that they knew all Christian neighbors whereas, $38.2 \%$ knew some of their Christian neighbors. Only $2.9 \%$ of Muslims did not know their Christian neighbors.

Question two yielded positive responses from Christians as well as Muslims. Table 2 illustrates that $95.5 \%$ of Christians claimed that their Muslim neighbors greeted them frequently while 3.9\% asserted that their Muslim neighbors greeted them occasionally. Similarly, $90 \%$ of Muslims positively answered that their Christian neighbors greeted them frequently whereas, $8.8 \%$ claimed that their Christian neighbors greeted them sometimes. The table indicates that quite insignificant respondents never greet each other. 
Table 2. Do your Muslim/Christian neighbors greet you?

\begin{tabular}{cccccc}
\hline Christians' Response & Frequency & Valid Percent & Muslims' Response & Frequency & Valid Percent \\
\hline Often & 170 & 95.5 & Often & 153 & 90.0 \\
Sometimes & 7 & 3.9 & Sometimes & 15 & 8.8 \\
Never & 1 & .6 & Never & 2 & 1.2 \\
Total & 178 & 100 & Total & 170 & 100 \\
Missing & 0 & 0 & Missing & 0 & 0 \\
Total & 178 & 100.0 & Total & 170 & 100.0 \\
\hline
\end{tabular}

Table 3. Do your Muslim/Christian neighbors wish you Christmas/Eid?

\begin{tabular}{cccccc}
\hline Christians' Response & Frequency & Valid Percent & Muslims' Response & Frequency & Valid Percent \\
\hline Often & 73 & 41.1 & Often & 122 & 72.0 \\
Sometimes & 34 & 18.4 & Sometimes & 29 & 17.0 \\
Never & 69 & 39.4 & Never & 19 & 11.0 \\
Total & 176 & 98.9 & Total & 170 & 100 \\
Missing & 2 & 1.1 & Missing & 0 & 0 \\
Total & 178 & 100.0 & Total & 170 & 100.0 \\
\hline
\end{tabular}

Table 3 reveals that $41.1 \%$ of Muslims were often wishing Christmas to their Christian neighbors while $18.4 \%$ were wishing occasionally. Correspondingly, $72 \%$ of Christians were often wishing Eid to their Muslim neighbors while $17 \%$ were wishing sometimes. These quantitative results were also supported by qualitative responses. An aged Christian clerk said; "On the occasion of every Eid we visit our Muslim friends to wish them, Eid". The Muslims interviewees' response was in negative when asked about visiting their Christian neighbors during Christmas. The researchers visited Jamia Uloom-ul-Islamia which shares a boundary wall with Saint Michael Catholic Church. The Orator of Jami 'ah commented; "On the occasion of every Eid, the Church officials come to Jami'ah to wish us, Eid. They also bring sweets on every Eid."

On the other hand, Saint Michael Catholic Church's priest commented: "The Jami 'ah's staff neither wish us Christmas nor do they visit us." However, both religious institutes cooperate on different levels as a senior student of the same Jami 'ah said; "When the Church staff asks us for something we provide them and we also send them meat on the occasion of Eid-ul-Azha." Another Mufti of Jami 'ah said that they had some legal issues to build a student's hostel in Jami 'ah and the Catholic Church priest and staff helped convince the government to allow us. This is a strong indicator of cooperative coexistence between both institutions.

Table 4. Do you visit your Muslim/Christian neighbors' homes?

\begin{tabular}{cccccc}
\hline Christians' Response & Frequency & Valid Percent & Muslims' Response & Frequency & Valid Percent \\
\hline Often & 75 & 42.4 & Often & 28 & 16.5 \\
Sometimes & 84 & 47.2 & Sometimes & 93 & 54.7 \\
Never & 17 & 9.3 & Never & 49 & 28.8 \\
Total & 176 & 98.9 & Total & 170 & 100 \\
Missing & 2 & 1.1 & Missing & 0 & 0 \\
Total & 178 & 100.0 & Total & 170 & 100.0 \\
\hline
\end{tabular}

Table 4 shows that $42.4 \%$ of Christians often visited their Muslim neighbors' home while $47.2 \%$ visited sometimes. $9.7 \%$ of Christians did not visit their Muslim neighbors' homes. On the other hand, table 4 further reveals that $16.5 \%$ of Muslims frequently visited their Christian neighbors' homes whereas, $54.7 \%$ of Muslims sometimes visited their Christian neighbors' homes. $28.8 \%$ of Muslims reported that they had never visited their Christian neighbors' homes. A common Christian said: “I often visit my Muslim neighbor's home. We are good friends and they (Muslim friends) sometimes invite me for dinner." 
Table 5. Do your Muslim/Christian neighbors invite you to their marriage ceremony?

\begin{tabular}{cccccc}
\hline Christians' Response & Frequency & Valid Percent & Muslims' Response & Frequency & Valid Percent \\
\hline Often & 127 & 70.9 & Often & 127 & 74.7 \\
Sometimes & 34 & 19.4 & Sometimes & 33 & 19.4 \\
Never & 14 & 8 & Never & 10 & 5.9 \\
Total & 175 & 98.3 & Total & 170 & 100 \\
Missing & 3 & 1.7 & Missing & 0 & 0 \\
Total & 178 & 100.0 & Total & 170 & 100.0 \\
\hline
\end{tabular}

Table 5 indicates that $70.9 \%$ Muslims often invite their Christian neighbors in their marriage ceremonies while 19.4\% Muslims invite them sometimes and $8 \%$ never invite their Christian neighbors in their marriage ceremonies. On the other hand, Muslims reported that $74.7 \%$ of their Christian neighbors often invite them in their marriage ceremonies while $19.4 \%$ claimed that they were invited a few times. Only $5.9 \%$ of Muslims reported that their Christian neighbors did not invite them to their marriage ceremonies. A Christian Consular of the Union Council commented; "Our Muslim neighbors, whom we know, always invite us in their marriage ceremonies and the same we do."

Table 6. Do you attend your Muslim/Christian neighbors' funeral ceremony?

\begin{tabular}{cccccc}
\hline Christians' Response & Frequency & Valid Percent & Muslims' Response & Frequency & Valid Percent \\
\hline Often & 149 & 84 & Often & 123 & 72.4 \\
Sometimes & 20 & 11 & Sometimes & 40 & 23.5 \\
Never & 8 & 4.4 & Never & 7 & 4.1 \\
Total & 177 & 99.4 & Total & 170 & 100 \\
Missing & 1 & .6 & Missing & 0 & 0 \\
Total & 178 & 100.0 & Total & 170 & 100.0 \\
\hline
\end{tabular}

Table 6 shows that $84 \%$ of Christians reported that they often attended their Muslim neighbors' funeral ceremonies while $11 \%$ of Christians joined a few times and $4.4 \%$ never attended any. $72.4 \%$ Muslims often attended their Christian neighbors' funeral ceremonies whereas, $23.5 \%$ attended sometimes and only $4.1 \%$ never attended.

Table 7. Do you feel safe among the Muslim community surrounding you?

\begin{tabular}{ccccc}
\hline Christians' response & Frequency & Percent & Valid Percent & Cumulative Percent \\
\hline Yes & 170 & 95.5 & 95.5 & 95.5 \\
No & 8 & 4.5 & 4.5 & 100.0 \\
Total & 178 & 100.0 & 100.0 & \\
\hline
\end{tabular}

Question 7 was only asked from the Christian respondents as they are a minority. Table 7 shows that widely held 95.5\% Christians felt safe in their Muslim neighborhood while 4.5\% of Christians did not feel safe in the Muslim community.

\subsection{Discussion of Overall Quantitative Data}

To find out the broad picture of Christian-Muslim neighborhood interaction the following quantification and calculation have been done. Interaction in the neighborhood based on the positive responses of both groups is measured separately as well as collectively. Hence, positive neighborhood interaction of Christians with Muslim neighbors was calculated as $71 \%$ (Note 4) while positive Muslim interaction with Christian neighbors found was 64\%. (Note 5) By merging positive responses of both communities the average percent neighborhood interaction of Christians and Muslims measured was 68\%. (Note 6)

From the results above it is obvious that the majority of the Muslim and Christian respondents knew their neighbors (Table 1) and were frequently greeting each other (Table 2). They often wished religious festivals to each other but the Muslim response in this regard was below average (Table 3) indicating that they were not 
frequently wishing Christmas to their Christians neighbors. Regarding visiting each other's homes, Christians were found to be more active in visiting their Muslim neighbors' homes as compared to Muslims visiting Christian's homes (Table 4). The majority of both groups claimed that they were invited by their neighbors in their marriage ceremonies (Table 5). The majority of Christians, as well as Muslims, insisted that they often attended their neighbors' funeral ceremony (Table 6). Moreover, the majority of $95.5 \%$ of Christians agreed that they were safe among the Muslim community of Peshawar. Further, when we quantified the positive observations of all items the Christian interaction with Muslims was recorded as $71 \%$ whereas, positive Muslim interaction with the Christian community was found $64 \%$. The overall quantified cross-religious neighborhood interaction was $68 \%$ which is above average and reveals a positive interaction between both communities.

\subsection{Discussion of the Qualitative Data}

As mentioned above, qualitative data was collected through group discussions and interviews. In the group discussions, the Christian participants were asked the following questions about their social interaction with Muslims.

1. What type of threat, if any, they feel from the Muslim community?

2. Which actions of the Muslim neighbors they like or dislike the most?

3. Do they face any problems from the Muslim community?

Virtually, all the interviewees answered that they had not received any threat nor faced any persecution or attack from the Muslim community. Similarly, nobody from the participants reported specific actions of their Muslim neighbors or coworkers which they disliked. Almost all the participants termed their Muslim neighbors as good and supportive fellows. A Christian Counselor of the Union Council said: "When a Christian has any tussle with any Muslim, Muslim neighbors stand in favor of Christian if Muslim is found guilty. This is the best example of equality of our Muslim neighbors which I like the most." To the third question, all of the participants insisted that they had no problem with the Muslim community. Most of the respondents stated that they had never experienced any big problem from their Muslim neighbors. In addition to this, a closed-ended question was asked solely from the Christian respondents in the questionnaire whether they felt safe in the Muslim neighborhood or not. Table 7 reveals that $95.5 \%$ of the respondents claimed that they were safe in their Muslim neighborhoods.

Similar responses appeared during the interviews. For instance, during an interview, a Catholic priest of Saint Michael Church was asked whether he knew about any clash in Peshawar between Christians and Muslims. He replied in these words: "According to my knowledge, no incident has occurred in which a Muslim crowed have attacked or persecuted any Christian in Peshawar." He further added: "The Christians are safe here because the government of KPK gives more protection to minorities as compared to other provinces of Pakistan."

Another interviewee, the bishop of KPK narrated an incident which highlights the cordial relations between Muslim and Christian communities in Peshawar:

When All Saint Church was attacked by terrorists in September 2013, the surrounding Muslim neighbors sympathetically cooperated with affected Christians. They excavated burial chambers for the deceased and provided food to the affected families continuously for three days. And when a prayer ceremony for martyred was held in Saint John Church they arranged prepared food for the entire congregation.

The Bishop of KPK, made another comment in the following words: "I visit different places of KPK but the Christian community has received neither any threat nor any attack from the Muslim community. The people who attack Christians and Muslims are anti-Pakistan elements. In KPK very few conflicts had occurred among Christians and Muslims but those were remarkably resolved peacefully. Here, Muslims and Christians are socially closer to each other as compared to other provinces." On the other hand, a Muslim Mufti of Jami 'ah Ulum-ul-Islamia said: "When the late Maulana Hassan Jaan was martyred by terrorists, we received condolence letters from all the churches of Peshawar."

These statements imply that at the neighborhood level both communities have a good social relationship and the Christian minority faces no significant problems from the Muslim community during everyday life in Peshawar city.

\section{Conclusion and Recommendations}

\subsection{Conclusion}

The above results lead to the conclusion that all in all Christian-Muslim communities enjoy peaceful coexistence in Peshawar city and their social interaction is positive at the neighborhood level. They have been living together 
for a long time and face no problem from each other in running their routine life. The absence of communal riots among Christians and Muslims of Peshawar also indicates their peaceful coexistence and positive social interaction with each other.

It has been noted in the beginning that at least two incidents of terrorist attacks against the Christian community happened in Peshawar. However, the matter of fact is that similar terrorist attacks by extremist groups took place against their Muslims neighbors as well. The problem of terrorism is related to several factors, which include, most importantly, the geopolitics of various regional and international stakeholders. This does not necessarily relate to the matter of coexistence and social interaction of the various communal groups in Pakistan.

One possible reason for the general good social bonds between Christians and Muslims in Peshawar city can be related to what Khan and Rafi (2014) claim that "KPK is relatively better [place to live] for the Christian community of Pakistan." Along this line of argument, a possible reason for the negative perception about the Christian minority in Pakistan can be the misplaced focus of media on selected violent incidents of communal violence that took place in particular localities like Gojra and Lahore, and then these images are projected over the whole country. Therefore, we argue that sweeping negative statements about the minority situation in Pakistan need to be circumvented and the fact should be taken into consideration that the results may vary from place to place.

However, to be candid, the study of a particular city alone cannot substantiate the conclusion that its situation regarding the treatment of a certain minority is better or worse than other parts of the country. Such a conclusion can only be drawn based on comparative social scientific studies about different provinces or cities of Pakistan, which according to our knowledge still needs to be undertaken. Though a case study about the Christian minority in Lahore (Chawla, 2018) has been undertaken it does not quantitatively study social interaction between Christians and Muslims the way it has been done in the present study. Thus a comparison between situations of the two cities is not plausible.

Therefore, the present study potentially points to the probability that there exists constructive and peaceful social interaction between different religious communities in Pakistan compared to the impression created by the situation reports which are based mostly on media reports and theoretical studies. Hence, we argue that claiming the widespread violence against Christians (Gregory, 2008) and sweeping statements that religious minorities in Pakistan are oppressed and threatened (2011, p. 49) are possibly making a mountain out of a molehill. Such assessments need to be counterchecked by empirical studies of specific localities of the country.

It is, however, not to state that nothing needs to be done regarding the socio-political situation of the minorities, including the Christian minority, in Pakistan. It is noteworthy that the present study has also yielded about $32 \%$ negative social interactions between Christians and Muslims in Peshawar which suggests the existence of some inter-communal problems. Besides, a sizable number of Christians live in a separate neighborhood called Christian Colony, on the outskirts of Peshawar, just like separate Christian neighborhoods exist in many other cities of Pakistan. This fact implies a lack of social integration and a need for improvement in the situation.

\subsection{Recommendations}

We recommend for both Christian and Muslim communities of Pakistan to promote those teachings of their respective religious traditions which could help and support their peaceful and harmonious coexistence in the country. Both Christianity and Islam uphold social and moral values like, justice, human dignity, and rights of neighbors, which are conducive to constructive and durable social interaction between different communities of the society.

Since the majority is always expected to play the leading role in achieving peaceful coexistence in any society, the Muslim community leaders should highlight the teachings of Islam about justice, the sanctity of human life, and the protection of religious minorities through media and the educational system of the country. The imams should speak on the rights of minorities in Islam during their Friday sermons.

It is the constitutional responsibility of the state to protect the life, dignity, and property of all its citizens and ensure equal opportunities for social and economic prosperity for everyone, including the minorities. As a practical measure, the Ministry of Religious Affairs and Inter-faith Harmony can play its role by establishing a formal forum for interfaith dialogue to promote mutual understanding among various religious communities of the country.

Some problems of the Christian community relate to their priorities. For instance, in one of the interviews during this study a Catholic priest of Saint Michael Church said: "Our Christian fellows earn money and spend it extravagantly instead of spending it on the education of their children. They do not try to improve their social 
status." So, the Christian community of Pakistan also needs to focus on education and community work to upgrade its economic and societal position in the country.

\section{References}

(n. d.). Retrieved from Peshawar Diocese: https://peshawardiocese.org/about-us/

(2011). A report on Religious Minorities in Pakistan. Lahore: National Commission for Justice and Peace.

The Constitution of the Islamic Republic of Pakistan. (2012). Retrieved from National Assembly of Pakistan: http://www.na.gov.pk/uploads/documents/1333523681_951.pdf

Pakistan church bomb. (2013, September 25). Retrieved from The Guardian: https://www.theguardian.com/world/2013/sep/23/pakistan-church-bombings-christian-minority

Situation of Christians in Pakistan, including social and government attitudes, treatment and rights (2010-2012). (2013, January 14). Retrieved from Immigration and Refugee Board of Canada: https://www.refworld.org/docid/510f8dbd2.html

World Directory of Minorities and Indigenous Peoples-Pakistan: Christians. (2018, June). Retrieved from Minority Rights Group International: https://www.refworld.org/docid/5ba0ae0e7.html

Ali, M. (2013, September 23). Interfaith harmony: The church that looked like a mosque. Retrieved from The Express Tribune: http://tribune.com.pk/story/607886/interfaith-harmony-the-church-that-looked-like-a-mos que

Ambreen, Q. (2014). Representation of Religious Minorities in Pakistani Print Media: a study of Daily Dawn, the News and the Nation. American International Journal of Contemporary Research, 4(1), 140-156. Retrieved from http://www.aijcrnet.com/journals/Vol_4_No_1_January_2014/15.pdf

Ballard, R. (2015). The Christians of Pakistan: A Historical Overview and an Assessment of their Current Position. Centre for Applied South Asian Studies (CASAS), 1-28. https://doi.org/10.11588/xarep.00003372

Carl, M. Love R. \& Micheli, J. (2011, September 6). Have Muslim-Christian Relations Improved Since 9/11? Retrieved from Christianity Today https://www.christianitytoday.com/ct/2011/september/muslim-christianrelations.html

Chawla, M. I. (2018). Focusing on Marginalized Groups in Pakistan: A Case Study of Christian Minority in Lahore. Journal of Social Sciences and Humanities, 26(2), 105-116. Retrieved from http://jssh.aiou.edu.pk/ wp-content/uploads/2019/04/7-Iqbal-Chawla.pdf

Elliott, A. (2006). The Cambridge Dictionary of Sociology (1st ed.). (B. S. Turner, Ed.) Cambridge, UK: Cambridge University Press.

Gabriel, T. (2007). Christian Citizens in an Islamic State: The Experience of Pakistan. Hampshire: Ashgate.

Ghazi, S. R., Shahzada, G., Khan, I., Shabeer, M. N., \& Shah, M. T. (2011). Content Analysis of Textbooks of Social and Pakistan Studies for Religious Tolerance in Pakistan. Asian Social Science, 7(5), 145-150. https://doi.org/10.5539/ass.v7n5p145

Gregory, S. (2008, July 17). The Christian Minority in Pakistan: Issues and Options. Pakistan Security Research Unit (PSRU), (37), 1-18. Retrieved from https://pdfslide.net/documents/38664081-the-christian-minorityin-pakistan-issues-and-options.htm

Ihsanullah. ( 2013, January 22 ). Edward Mission Higher Secondary School Peshawar. Retrieved from My Official Add: https://ihsanullah16.blogspot.com/2013/01/edward-mission-higher-secondary-school.html

Jan, A. (2013, September 23). Remembering Peshawar's All Saints church. Retrieved from Qissa Khwani: https://qissa-khwani.blogspot.com/2013/09/remembering-peshawars-all-saints-church.html

Kriesberg, L. (2001). Changing Forms of Coexistence. In M. Abu-Nimer (Ed.), Reconciliation, Justice, and Coexistence: Theory and Practice (pp. 47-64). New York: Lexington Books.

Malik, I. H. (2002). Religious Minorities in Pakistan (pp. 1-32). London: Minority Rights Group International. Retrieved from https://www.refworld.org/pdfid/469cbfc30.pdf

Misra, A. (2015). Life in Brackets: Minority Christians and Hegemonic Violence in Pakistan. International Journal on Minority and Group Rights, 22(2), 157-181. https://doi.org/10.1163/15718115-02202002

Mondal, P. (n. d.). Social Interaction: What is Social Interaction? Retrieved from http://www.yourarticlelibrary. $\mathrm{com} /$ sociology/social-interaction/social-interaction-what-is-social-interaction/31278 
Pakistan Bureau of Statistics. (n. d.). Retrieved from Population by Religion: http://www.pbs.gov.pk/sites/ default/files//tables/POPULATION\%20BY\%20RELIGION.pdf

Pennink, J. J. (2010). The Essence of Research Methodology: A Concise Guide for Master and PhD Students in Management Science. Heidelberg: Springer.

Qusien, \& Amber, M. R. (2017). Minorities in Pakistan: Role of Pakistani Private TV Channels in Highlighting Minorities' Rights. Online Journal of Communication and Media Technologies, 7(2), 96-113. https://doi.org/10.29333/ojcmt/2593

Rafi, Khan. M. S. \& G. (2014). Religion, Politics and the Christians of Pakistan: Is KPK a Better Option to Live? Middle-East Journal of Scientific Research, 21(6), 975-983. https://doi.org/10.5829/idosi.mejsr.2014. 21.06 .21552

Rainaa, A. K. (2014). Minorities and Representation in a Plural Society: The Case of the Christians of Pakistan. South Asia: Journal of South Asian Studies, 37(4), 684-699. https://doi.org/10.1080/00856401.2014.966945

Rummel, R. (1976). Understanding Conflict and War: The Conflict Helix (Vol. 2). California: Sage Publications. Retrieved from https://www.hawaii.edu/powerkills/TCH.CHAP9.HTM

Seiler, R. (2014). Christian Persecution in Pakistan: An Examination of Life in the Midst of Violence. (Senior Honors thesis, Liberty University, Lynchburg, Virginia). Retrieved from https://digitalcommons.liberty. edu/cgi/viewcontent.cgi?article=1492\&context=honors

Shamsi, A. H. (2011). Social Status and Political Participation of Christian Minority in Pakistan. (Doctoral dessertation, University of the Punjab, Quaid-e-Azam Campus, Center for South Asian Studies, Lahore, Pakistan).

Shahzad, Shumaila A,. Hassan A \& R. (2014). Minority Rights as Human Rights: Hegemonic Media Representation of Minority Groups in Pakistan. The International Asian Research Journal, 7(1), 28-35.

Singh, Y. K. (2006). Fundamental of Research Methodology and Statistics. New Delhi: New Age International.

Smith, S. (2015, October 12). Muslim mob tries to lynch Christian family. Retrieved from The Christian Post: https://www.christianpost.com/news/muslim-mob-lynch-christian-family-father-accused-blasphemy.html

Tarar, Rukhi. K. \& A. (2004). Effects of Cross Categorization on Inter-Group Perception of Muslims and Christians in Pakistan. Pakistan Journal of Social and Clinical Psychology, 2(1), 3-16. Retrieved from https://psycnet.apa.org/record/2007-13362-001

Yousaf, F. (2016). SADF Focus: The Plight of Religious Minorities in Pakistan. South Asian Democratic Forum (SADF). https://doi.org/10.13140/RG.2.2.17953.92000

Yusof, N. M. (2006). Pattern of Social Interaction between different Ethnic Groups in Malaysian Secondary Schools. Jurnal Pendidik dan Pendidikan, 21, 149-164. Retrieved from http://web.usm.my/apjee/APJEE_ 21_2006/10\%20najeemah(149-165).pdf

Yusufzai, M. (2016, September 2). Suicide Bombers Strike Christian Community near Warsak Dam in Pakistan. Retrieved December 24, 2019, from NBC News: Retrieved from https://www.nbcnews.com/news/world/ attackers-strike-government-targets-near-peshawar-pakistan-n641871

Zafar, M. I. (2000). Impact of Christian Missionary Activities on Muslim Society: A Case Study of Jampur; A Pakistani Community in Socio-Religious Context (Doctoral Dissertation, University of Punjab, Lahore, Pakistan).

Zaidi, S. S. A. (1988). Religious minorities in Pakistan today. Journal of Contemporary Asia, 18(4), 444-457. https://doi.org/10.1080/00472338880000331

Zia, Saeed.-ur.-Rahman, A. S. (2010, January). The Impact of Educational Policies on Religious Minorities of Pakistan: 1947-2010. South Asia Forum for Human Rights, 1-48. Retrieved from https://archiv.zmo.de/publikationen/2010/The\%20Impact\%20of\%20Educational\%20Policies\%20on\%20the \%20Religious\%20minorities\%20of\%20Pakistan.pdf

\section{Notes}

Note 1. He was a major-general in the East Indian army of the British Indian Empire. He was graduated from the King's College, London see his full profile at http://www.1902encyclopedia.com/E/EDW/sir-herbert-benjaminedwardes.html 
Note 2. It was recorded from the Foundation Stone of the Church during field work.

Note 3. Said by the Church's priest.

Note 4. Explanation: Sample mean $=x=\sum \mathrm{f} / \mathrm{N}$, OR $x \%=\sum \mathrm{f} / \mathrm{N} \times 100, \mathrm{X}=885 \div 1238 \times 100=71 \%$, Where $\sum \mathrm{f}$ is the sum of all the positive frequencies (i,e Often), $\mathrm{N}$ is the number of population (Christians) observations.

Note 5. Explanation: Same formula, $\sum \mathrm{f}=653, \mathrm{~N}=1020, \Rightarrow>653 \div 1020 \times 100=64 \%$.

Note 6. Mean percent $=x \%=\sum \mathrm{f} / \mathrm{N} \times 100,1538 \div 2258 \times 100=68 \%$, Where $\sum \mathrm{f}$ is the sum of all the positive frequencies, $\mathrm{N}$ is the number of population (Christians-Muslims) observations.

\section{Copyrights}

Copyright for this article is retained by the author(s), with first publication rights granted to the journal.

This is an open-access article distributed under the terms and conditions of the Creative Commons Attribution license (http://creativecommons.org/licenses/by/4.0/). 